УДК $80.01-2$

Васильев $\boldsymbol{G . ~ М . , ~}$ кандидат філологічних наук, доцент, докторант Житомирського державного університету імені Івана Франка

\title{
ДРАМА-СІКВЕЛ: ОСОБЛИВОСТІ ПОЕТИКИ
}

Статтю присвячено новітній жанровій формі, яка виникла у сучасній драматургії наприкінці XX століття. Розглянуто репрезентативні зразки драми-сіквелу (n'єси Г. Горіна, Б. Акуніна, О. Шишкіна, І. Вирипаєва. Т. Слободзянека, Т. Ружевича), проаналізовано риси ї̈ поетики.

Ключові слова: драма, сіквел, постмодернізм, постсюжет, хронотоп, персоносфера.

Статья посвящена новейшей жанровой форме, возникшей в современной драматургии в конце XX века. Рассмотрены репрезентативные образцы драмы-сиквела 
(пьесы Г. Горина, Б. Акунина, О. Шишкина, И. Вырыпаева. Т. Слободзянека, Т. Ружевича), проанализированы черты ее поэтики.

Ключевые слова: драма, сиквел, постмодернизм, постсюжет, хронотоп, персоносфера.

The article deals with the lattest genre forms which have appeared in drama at the end of the XX century. The representative examples of play-sequel (G. Gorin, B. Akunin, O. Shishkin, I. Vyrypayev. T. Stobodzianek, T. Różewicz), are considered. Features of its poetics are analyzed.

Key words: drama, sequel, postmodernism, post subject, chronotope, characters.

Поняття сіквелу (від англ. sequel - результат, наслідок) зобов’язане своєю появою кіномистецтву. Це продовження кінофільму, який користувався комерційним успіхом, як правило, 3 тими ж акторами в головних ролях. Згадаймо, приміром, по два сіквели «Хрещеного батька» та «Матриці», продовження таких голівудських кінопродуктів, як «Горець», «Кошмар на вулиці В’язів», «Крик», «Термінатор», «Чужий» або ж російські сіквели фільмів «Брат» та «ДМБ».

3 кінематографу жанр сіквелу перейшов до інших видів мистецтва. Найбільш успішно він прижився у масовій літературі: від «Пригод Шерлока Холмса», що дописані сином письменника Адріаном Конан Дойлем, і сіквела роману М. Мітчелл «Завіяні вітром» «Скарлетт» А. Ріплей до двох «нових» томів «Війни і миру» «П’єр і Наташа» Василя Старого, які 1996 р. надрукувало видавництво «Вагріус».

3’явився сіквел у 1990-ті роки і в драматургії, де він, звичайно, не ставив собі за мету лише комерційний успіх. Сіквел у драмі - це постсюжет, заснований на іронічній грі 3 класикою, на діалозі насамперед 3 відомими, навіть міфологізованими текстами світової культури. Прикладами драмисіквела $є$ «Остання жінка сеньйора Хуана» Леоніда Жуховицького (постсюжет багатовікового літературного міфу про севільського перелюбника), «Чума на ваші дві домівки...» Григорія Горіна (продовження «Ромео і Джульєтти» Шекспіра), «Чайка» Бориса Акунина (сіквел однойменної п’єси А. П. Чехова), «Анна Кареніна II» Олега Шишкіна (продовження знаменитого роману Л. М. Толстого), «Валентинів день» Івана Вирипаєва (сіквел п’єси М. Рощина «Валентин і Валентина»), «Сон Клопа, або Товариш Христос» (завершення комедії «Клоп» В. Маяковського), «Розкидана картотека» Т. Ружевича 
(продовження його ж драми «Картотека»), «Що сталося після того, як Нора залишила чоловіка, або Стовпи суспільства» Ельфріди Слінек (продовження драми Г. Ібсена «Ляльковий будинок»).

Усі зазначені п’єси у сюжетному відношенні $є$ безпосередніми продовженнями своїх «вихідних» текстів. Так, дія сіквела Г. Горіна «Чума на ваші дві домівки...» (1993) розпочинається з траурної процесії за загиблими закоханими, під час якої Герцог Веронський вирішує примирити Монтеккі та Капулетті, зробивши їх ріднею: «Я назначаю свадьбу двух семей! Монтекки пусть подыщут жениха! Пусть Капулетти подберут невесту! И за огромным свадебным столом Я две семьи соединю в одну, Навечно прекратив вражду и распри!..» [Горин 1997:407]. Але показово, що ще до початку драматичної дії у п’єсі Горіна міститься невеличкий Пролог, в якому з'являється Хор, котрий наче обгрунтовує саме звернення до жанру драматичного сіквелу: «Почтеннейшая публика! Для вас Mbl вспомнили старинную легенду, Рассказанную много лет назад, Воспетую Банделло и Шекспиром (А может быть, и кем-нибудь ещуе, Но менее известным и забытым...) Давно замечено: у истинных легенд Нет окончаний, есть лишь продолженья» [Горин 1997:404].

Слід зауважити, що над особливостями жанру п’єси-сіквела розмірковують не лише дійові особи (що безперечно надає п’єсам метатеатрального характеру), але й самі автори (наприклад, Олег Шишкін в авторській передмові до драми «Анна Каренина II» (2001) [Шишкин 2016]. У самому ж сіквелі О. Шишкін вдається до «воскресіння» толстовської героїні. Анна дійсно не померла, незважаючи на «ужасные paны, несовместимые $c$ жизнью». «После случивщегося, - розповідає Кареніну хірург, - мы ампутировали у нее ногу и руку. К тому же травма головы была столь серьезной, что она потеряла глаз. Но зато она жива» [Шишкин 2016]. Проте якщо драматург «пошкодував» Анну (вона поступово одужує, а протези повертають їй рух), то до Вронського Шишкін безжалісний. Після удаваної смерті своєї коханки («в горячечном бреду ему казалось, что он присутствовал на ваших похоронах») він відправився в діючу армію на Балкани, де був 
поранений. «Алексей теперь неподвижен и ничего ровным счетом не помнит, не говорит. Он просто существует» [Шишкин 2016], - говорить мати Вронського. Ефектною у своєї гротесковості та трагіфарсовості є сцена 13 («У Вронских»), що зображує зустріч двох калік: «Анна крутит колеса креслакаталки и подъезжает к креслу-каталке Алексея и начинает целовать Вронского не сдерживая чувств. Вронский от переизбытка чувств Анны падает с коляски на пол. Анна в ужасе сползает со своей коляски и пытается из всех сил поднять Вронского и усадить на место. Из-за двери раздается голос Каренина: "Анна много страдала, но страдания, кажется, пошли ей на пользу» [Шишкин 2016].

«Страждає» у п’єсі-сіквелі О. Шишкіна і Костянтин Льовін. Причиною його страждань $є \ldots$ любов до Анни. Невдовзі після любовної сцени з нею Льовін абсурдно гине («Он был задавлен повалившимся телеграфным столбом u погиб мгновенно»). А в останній сцені драми помирає й сама Анна. Причому, як і в толстовському романі, від потягу, щоправда, не реального, а, сказати б, віртуального. О. Шишкін знайшов оригінальний сюжетний хід, відправивши Анну 3 чоловіком у сінематограф. «Mbl предупреждаем вас, что эффект воздействия этого аппарата столь силен, что способен вызвать нервный припадок и обморок у чувствительных дам» [Шишкин 2016], - застерігає публіку директор. I глядачам демонструють знамените «Прибуття потяга» братів Люм'єр, що впливає на героїню не просто надзвичайно, але й смертельно: «Боже мой! Поезд! Поезд! Какая сила разрывает меня в этот час! Когда чудовищные поезда врываются на чудовищные вокзальи! Реальные могли искромсать мое тело! Чудовищные уничтожают меня совсем! Нет больше сантиментов! Нет больще первородных поцелуев! Только паровозный гудок! Шквал паровозных гудков над всей Россией! И искореженные миллионы человеческих тел остаются на рельсах этого космоса. Это смерть реальности, ее полная, несуществующая аналогия!» [Шишкин 2016].

Отже, виживши під колесами справжнього поїзду, Анна гине від його віртуального двійника. Ця ефектна фінальна сцена сходження «двох» поїздів 
(толстовського і люм’єрівського) надзвичайно цікава й тим, що, як відзначає Ю. Ців'ян, ранні російські фільми за романом «Анна Кареніна» відтворювали сцену самогубства Анни не «за Толстим», а «за Люм'єрами». Щоправда, тоді йшлося не про усвідомлену інтертекстуальність, а, скоріше, про безсвідоме копіювання зразка, що залишив неперевершене враження жаху від потягу, який насувався на глядача [Цивьян 1991:165-167].

«Чайка» Бориса Акуніна є своєрідним п’ятим актом, дописаним до знаменитого чеховського твору. На початку свого сіквела Акунін повністю репродукує «Чайку» Чехова, а потім надає читачеві кілька варіантів розвитку подій. Іноді для цього він вводить власну останню сцену четвертої дії, в якій змінює лише ремарки, від чого значення слів персонажів кардинально змінюється.

У всіх варіантах акунінської «Чайки» роль слідчого бере на себе доктор Дорн, розповідаючи про свою спорідненість із династією фон Дорнів. Таким чином, Акунін проводить своєрідну паралель із героєм своїх детективів Ерастом Петровичем Фандоріним (цілком ймовірно, що саме співзвуччя Дорна 3 Фандоріним і наштовхнуло Бориса Акуніна на думку про експериментальну п’єсу-сіквел). Кожен раз смерть Треплева, що відбулася в кінці чеховської «Чайки», представлена по-різному. Це i підтвердження його самогубства, i вбивство найрізноманітнішими, часом несподіваними учасниками п’єси, в останньому ж варіанті у вбивстві Треплева зізнається сам Дорн.

У нелінійному тексті постмодерністської «Чайки» Б. Акуніна реалізуються принципи як філософії можливих світів, так і поліваріантність сюжетних ходів. Подібними прийомами в другій половині XX століття нерідко користуються прозаїки («В гаю» Акутагави Рюноске, «Три версії зрадництва Іуди», «Сад розбіжних стежинок» Хорхе Луїса Борхеса), драматурги («Гра» Семюеля Беккета, «Біографія» Макса Фріша), і кінорежисери («Расьомон» Акіро Куросави, «День бабака» Гарольда Раміса, «Біжи, Лола, біжи» Тома Тиквера). 
П’єса Івана Вирипаєва «Валентинів день» (2001) є сіквелом по відношенню до відомої драми Михайла Рощина «Валентин і Валентина». Валентині у вирипаєвській п’єсі вже шістдесят, проте вона, як і раніше, живе в минулому, іï так само мучить любов до Валентина. Він іще в 1970-ті одружився на сусідці Каті. I через п’ятнадцять років, випадково зустрівши Валентину в метро, він розуміє, що не може без неї жити. П'ять років він мучиться, намагаючись «розділити себе» між двома жінками, а потім помирає від розриву серця в день народження Валентини. Наступні двадцять років обидві жінки, пов’язані одним чоловіком та однією пристрастю, живуть поруч. Валентина i Катя ненавидять одна одну, мучать, але минуле буквально «проковтнуло» їх вони не в силах розлучитися, з’єднані спільним болем. Вони відчайдушно намагаються зрозуміти себе і пробачити один одного.

Час у п’єсі плавно перетікає з минулого в майбутнє, що Вирипаєв наче виправдовує обраним епіграфом з арабського філософа Кори Аль Музані: «Не намагайтеся шукати логіку в часі - в часі логіки немає. Не намагайтеся пояснити час логічним шляхом, часу як такого не існує. $С$ дві речі: любов $i$ любов» [Вырыпаев 2016]. А зв'язок із рощинською драмою відверто демонструється впродовж усього тексту: починаючи від присвяти («Михайлу Михайловичу Рощฺнуу) до заголовків структурних елементів («Приход Катерины прошлого века за маслом прошлого века, в сиене из пьесы «Валентин и Валентина» второй половины прошлого века») [Вырыпаев 2016]. Окрім того, у драмі І. Вирипаєва містяться інтерполяції 3 «Валентина i Валентини» М. Рощина, що $є$ характерним для вторинних сюжетоутворюючих жанрів (наприклад, цитати 3 шекспірівського «Гамлета» у Стоппардовій п’єсі «Розенкранц і Гільденстерн мертві», або ж вставки 3 текстів В. Бєлінського, О. Герцена, I. Тургенєва та інших дійових осіб його ж драматичної трилогії «Берег утопії»).

Показово, як ця сюжетна вторинність і цитатність тексту I. Вирипаєва артикулюється і в жанрових підзаголовках вистав за його п’єсою, що увійшла до репертуарів численних театрів. У самого драматурга міститься оригінальна 
дефініція: «Мелодрама 3 цитатами у напряму примітивізму», що вона зберігається у жанрових найменуваннях театральних продуктів. Так, Молодіжний театр на Фонтанці (Санкт-Петербург) визначив жанр свого «Валентинового дня» (прем’єра 2010 року) як «Мелодраму 3 цитатами у напряму примітивізму в двох частинах», а Саратовський театр імені I. А. Слонова (прем’єра відбулася 2007 року) дає схожу дефініцію, в якій, окрім «цитатності», постульований і сам принцип сіквела - продовження: «таке собі продовження п’єси М. Рощина «Валентин і Валентина», а точніше мелодрама 3 цитатами у напряму примітивізму».

Проте не менш показовим $є$ й те, що у деяких виставах ознаки вирипаєвського сіквела зовсім не артикульовано. У Псковському академічному театрі драми імені О.С. Пушкіна (прем’єра 2011 р.) лише підкреслено мелодраматичний характер спектаклю («Сучасна мелодрама без антракту»). Те ж саме стосується київської вистави (Національний академічний театр російської драми імені Лесі Українки), яка іде 2004 р. лише 3 підзоголовком «драма», а також вистави у Мінську (прем’єра 2007 р.): «мелодрамою у двох діях» названий «Валентинів день» Національного академічного драматичного театру імені М. Горького. «Мелодрамою» названі вистави Челябінського театру «Манекен» (2012) і Новосибірського державного театру «Старий дім» (2009). А Калінінградський обласний драматичний театр змінив вирипаєвську «мелодраму 3 цитатами» на «трагікомедію в 2-х діях». Харківський центр сучасного мистецтва «Нова сцена» маркував у своєму «Валентиновому дні» (2005) імена відразу двох драматургів: «вистава за мотивами п’єс М. Рощина, I. Вирипаєва». А на афіші київського театру-студії "Splash” жанрове визначення взагалі відсутнє.

Список жанрових відповідностей i невідповідностей вистав за «Валентиновим днем» авторській жанровій креації можна продовжити. Нам би хотілося лише накреслити важливу існуючу проблему щодо сценічного втілення драматичних творів. Адже режисер-постановник, будучи сьогодні повноправним співавтором, співтворцем драматурга, може або слідувати за 
автором у жанровій, здебільшого оригінальній природі твору, або ж корегувати, редукувати цю природу, привносити у неї певні зміни. Думається, ця проблема, що носить виразно інтермедіальний характер, потребує окремого серйозного дослідження.

Драмою-сіквелом є також п’єса «Сон Клопа, або Товариш Христос» (1999) польського драматурга Тадеуша Слободзянека [Слободзянек 2003]. Ïї вихідним текстом $є$ «Клоп» В. Маяковського. Т. Слободзянек створює оригінальну варіацію на тему цієї сатиричної комедії. Сюжетною канвою стає продовження долі протагоніста «Клопа» Присипкіна. Нагадаємо, що у фантасмагоричній п’єсі В. Маяковського він прокидається у 1979 році (його розморожують у наукових цілях), через півстоліття після основних подій комедії. Присипкін вимагає від учених «заморозити його назад» і мешкає тепер у клітці зоосаду.

У сіквелі Слободзянека, що починається тим, чим «Клоп» В. Маяковського закінчується, Присипкіна випускають із клітки після падіння комунізму. 3 останнього буржуя він перетворився на останнього більшовика. Присипкін Слободзянека гуляє Москвою кінця 1990-х, спостерігаючи за розвалом СРСР та моральним занепадом у пострадянському суспільстві. Тепер він конфронтує з сучасними злочинцями i пророками, політиками i вкотре ошуканими людьми. Серед персонажів п’єси - «колишній легендарний генерал, нині політик, бізнесмен $і$ злочинещьь», «колишній лауреат Нобелівської премї в галузі матеріалізму, нині бездомний» [Слободзянек 2003:39]. Персонажі повсякденної дійсності зустрічаються тут поряд із фікційними - героями літератури та міфологізованої історії.

У п’єсі «Сон Клопа» зустрічаємось із реаліями не лише Росії, але й простору російської літератури: це i «булгаковські» Патріарші ставки, Воробйові гори та письменницька їдальня, це і пам’ятник Маяковському, біля підніжжя якого розгортається дія твору. Драма Т. Слободзянека наскрізь інтертекстуальна: вона наповнена цитатами 3 творів О. Пушкіна, Ф. Достоєвського, О. Блока, М. Булгакова, О. Мандельштама, В. Маяковського. 
Недаремно, за оцінкою відомого польського театрального критика Яцека Серадського, Т. Слободзянек, подібно до інших польських драматургів (С. Мрожек, «Любов у Криму» і Я. Гловацький, «Четверта сестра»), «поставився до Росії скоріше як до резервуару літературних мотивів, ніж як до реальності. Однак і в цю розповідь, повну відсилань до Булгакова або Срофєєва, він вклав свої питання про можливість здійснення вроджених людських уявлень про світопорядок посеред хаосу, питання про утопічність всякого раю, включаючи християнський» [Серадський 2003].

Нікчемний обиватель Присипкін з комедії Маяковського перетворюється на справжнього трагічного героя, жертву історії XX століття у Слободзянека. У фіналі він кидає Маяковському, який зійшов зі свого постаменту на Тріумфальній площі: «Для чого все чзе було? Після того, як ми розстріляли цุаря? А потім проливали свою $і$ чужу кров? Навіщуо ми помирали під Перекопом, а деякі навіть померли? Для чого нас на півстоліття заморозили? Навіщуо нас всіх випустили із клітки? I щзо нам тепер робити з цієюю свободою?» [Слободзянек $2003: 43$ ].

Цікавими є зразки автосіквелів - продовжень драматургами власних текстів. У цьому відношенні вельми показовим $є$ досвід польського митця Тадеуша Ружевича, два тексти якого - «Картотека» (1959) i «Розкидана картотека» (1993) - являють собою своєрідне обрамлення його творчості i перебувають між собою у своєрідних діалогічних стосунках. Якщо «Картотека» була дебютною п’єсою Т. Ружевича, на той час визнаного поета, автора дванадцяти поетичних книг, то «Розкидана картотека» стала його останнім твором для сцени. За висловом Г. Санаєвої, «Розкидана картотека», будучи варіантом дебютної п’єси, а також автокоментарем, «одночасно є своєрідним палімпсестом, що включає в себе як різноголосся сучасного світу, так i актуалізацію власного шляху в мистецтві» [Санаева 2009:22].

У першій «Картотеці» зображувався і піддавався вівісекції польський інтелігент, «Герой», який був людиною «без певного віку, занять $i$ зовнішності», i до того ж, за вступною ремаркою драматурга, «часто перестає 
бути героєм і його замінюють інші люди - також «герої», [Ружевич 1979:75], що розчарувався в соціалізмі «з людським обличчям». Безіменний герой Ружевича відмовляється що-небудь робити і демонстративно лягає в ліжко, поруч 3 яким розгортається історія. В новій «Картотеці» (яка, до речі, створювалась просто на репетиціях у вроцлавському Польському театрі) йшлося про розчарування героя нової доби - розчарування у знайденій свободі, демократії, вільному ринку.

Все, що стосується життя Героя в «Розкиданій картотеці», дублюється автором із незначними змінами з біографії Героя дебютної п’єси. Деякі сцени «Картотеки» майже дзеркально відображені у новій іiі «версії». Але Ружевич піддає їх значному скороченню й модифікації, вводить нових персонажів, поміщаючи їх у контекст сьогоднішніх реалій. Біографія Героя в «Розкиданій картотеці» скорочується до мінімуму, у читача все менше можливостей дізнатися про його минуле. Одночасна присутність Героя I та його копії у вигляді Героя II дозволяє Ружевичу «розосередити» факти з життя Героя по всьому твору і позбавити п’єсу умовного центру. I без того невизначена особистість Героя в «Розкидані картотеці» піддалася додатковому розщепленню і деструкції, він «тоне» в потоці інформації. Герой занурений вже не в потік власної свідомості, як у попередній версії п’єси, в сферу його «я» вторгається повсякденність, інформаційний шум, рекламні трюки, політичні дебати та інші прикмети нинішнього часу» [Санаева 2009:19-20].

Дві «Картотеки» перебувають у стані діалогу не лише за персоносферою, але й зближуються за поетикальними засобами. Польський театрознавець Роман Павловський зауважує: «як і в першій версії «Картотеки», Ружевич змішував у тексті літературну фабулу, особисті враження та цитати 3 преси. Повідомлення про торгівлю людськими органами сусідило 3 післявоєнними травмами, малозрозуміле белькотання 3 трибуни сейму - із полум'яними фразами ксьондза Пйотра Скарги, натхненного проповідника, що жив на зламі XI і XII сторіч... Ружевіч творить мову своєї п’єси 3 поквапливого бурмотіння мас-медій, інтерв’ю з політиками та газетних оголошень, у яких сексуальні 
послуги перемішані 3 рекламою ресторанів та автошкіл» [Павловський 2014:12-13].

Отже, можемо відзначити низку жанрових ознак драми-сіквела:

1. Сіквел апелює як до класичних («Ромео і Джульєтта» В. Шекспіра, «Чайка» А. Чехова), або принаймні знакових для певної епохи («Клоп», В. Маяковського, «Валентин і Валентина» М. Рощина) текстів світової драматургії і літератури і цілому («Анна Кареніна» Л. Толстого).

2. У сучасній драматургії трапляються i автосіквели («Розкидана картотека» Т. Ружевича), які продовжують існуючу в літературі поважну традицію так званого «авторського сіквела» («Віконт де Бранжелон» О. Дюма по відношенню до «Трьох мушкетерів», «Тьоркін на тому світі» О. Твардовського по відношенню до його ж поеми «Василій Тьоркін»).

3. Обов’язковий безпосередній лінійний сюжетно-фабульний зв’язок iз першотвором (присутній в усіх без винятку зразках жанру).

4. Нерідко дія драми-сіквела розпочинається 3 тих подій, якими завершується дія вихідного тексту («Чума на дві ваші домівки...» Г. Горіна, «Чайка» Б. Акуніна). Проте між ними можливий і певний часовий проміжок (п’ятнадцять років розділяють історії Валентина i Валентини в драмах M. Рощина й І. Вирипаєва; фінал «Клопа» В. Маяковського і початок «Сну Клопа» Т. Слободзянека відділяє два десятиріччя; дві «Картотеки» Т. Ружевича - понад чотири).

5. Хронотоп драми-сіквела відповідає часу та простору пов'язаної 3 ним п’єси («Чайка» Б. Акуніна, «Анна Кареніна II», О. Шишкіна).

6. Персоносфера драми-сіквела здебільшого дублює світ дійових осіб вихідної драми («Чайка» Б. Акуніна, «Анна Кареніна II», О. Шишкіна). Проте автор сіквела нерідко вводить нових оригінальних персонажів, відсутніх у прототексті (протагоністи Антоніо і Розалінда в «Чума на дві ваші домівки...» Г. Горіна, відсутні у шекспірівський «Ромео і Джульєтті», персонажі «Сна клопа» Т. Слободзянека: генерал Преображенський, Пророк тощо), які взаємодіють із запозиченими дійовими особами. 
7. Автори сіквела вільно поводяться у збереженні жанрових ознак першотексту. В одних випадках вони дотримуються жанрової конвенції та пафосу твору (Т. Ружевич), в інших - порушують їх (трагедія В. Шекспіра змінюється на трагікомедію у Г. Горіна, роман Л. Толстого перетворюється на трагіфарс у О. Шишкіна).

8. Поетикальні засоби й прийоми драми-сіквела відповідають аналогічним зразкам оригінальному твору («Картотека» $\mathrm{i}$ «Розкидана картотека» Т. Ружевича).

9. Драма-сіквел має відвертий цитатний, інтертекстуальний (I. Вирипаєв) та інтермедіальний (О. Шишкін) характер по відношенню як до вихідного тексту, так і до інших, знакових текстів доби, насамперед генетично і генологічно близьких до нього (світ російської літератури XIX-XX ст. у драмі Слободзянека: від «Мідного вершника» О. С. Пушкіна (Маяковський сходить зі свого постаменту подібно до Петра I у пушкінській поемі) до сатиричних повістей і драм М. О. Булгакова (пані Зося, що сходить до «Зойчиної квартири», або ж Преображенський, який перегукується 3 героєм «Собачого серця»; фільм братів Люм’ер «Прибуття потяга на вокзал Ла-Сіота» у драмі «Анна Кареніна II» О. Шишкіна).

\section{БІБЛІОГРАФІЯ}

Вырыпаев 2016 - Вырыпаев И. Валентинов день [Електронний ресурс] / Иван Вырыпаев. - 2016. - Режим доступу до ресурсу: http:/teatre.com.ua/ upload/all/lib/valentinsday.pdf.

Горин 1997 - Горин Г. И. Королевские игры / Григорий Израилевич Горин. - Москва: Стоок, 1997. - 472 с.

Павловський 2014 - Павловський Р. Навіщо ці п’єси з Польщі? / Роман Павловський // Сповідь після зламу. Антологія сучасної польської драматургії / Роман Павловський. - Київ: Темпора, 2014. - С. 4-40.

Ружевич 1979 - Ружевич Т. Избранное / Тадеуш Ружевич. - Москва : Художественная литература, 1979. - 318 с. 
Санаева 2009 - Санаева Г. Н. Поэтика драматургии Тадеуша Ружевича : автореф. дис. на здобуття наук. ступеня канд. філ. наук : спец. 10.01.03 «Литература народов стран зарубежья (литературы Европы)» / Санаева Галина Николаевна - Москва, 2009. - 24 с.

Серадський 2003 - Серадський Я. Драматургия после 1989-го: трудная свобода [Електронний ресурс] / Я. Серадський // Новая Польша 2003. - № 2 Режим доступу до ресурсу: http://archive.novpol.org/index.php?id=184.

Слободзянек 2003 - Слободзянек Т. Сон клопа, или Товарищ Христос : [Картины IV и V пьесы] / Пер. с пол. А. Железцова, А. Каневского / Тадеуш Слободзянек. // Новая Польша. - 2003. - №9. - С. 39-44.

Цивьян 1991 - Цивьян Ю. Г. Историческая рецепция кино. Кинематограф в России (1896-1930) / Юрий Гаврилович Цивьян. - Рига: Зенатне, 1991. - 246 с.

Шишкин 2016 - Шишкин О. Анна Каренина II [Електронний ресурс]/ Олег Шишкин. - 2016. - Режим доступу до ресурсу: http: // www.newdrama.ru/ plays/?play $=8$.

УДК $821.161 .2-31$

Веретюк T. В., кандидат філологічних наук, викладач кафедри української і світової літератури Харківського національного педагогічного університету імені Г. С. Сковороди

\section{ЖІНОЧІ ТИПИ В РОМАНІ ІГОРЯ МУРАТОВА «У СОРОЧЦІ НАРОДЖЕНИЙ»}

Ця стаття присвячена вивченню проблеми становлення людини у складних життєвих обставинах та розгляду другорядних жіночих образів роману, а також тих подій, щзо впливали на становлення та утвердження характерів ичих образів, розкриваються умови формування персонажів такого рівня.

Ключові слова: проблема, приклад, тип, характер, час, пристосуванство.

Эта статья посвящается изучению проблемы становления человека в трудных жизненных обстоятельствах и рассмотрению второстепенных женских образов романа, а также тех событий, которые влияли на становление и утверждение характеров этих образов, раскрываются условия формирования персонажей такого уровня.

Ключевые слова: проблема, пример, тип, характер, время, приспособленчество. 